\title{
Chapter Eight
}

\section{The Half-Caste in Australia, New Zealand, and Western Samoa between the Wars: different problem, different places? ${ }^{1}$}

\author{
Vicki Luker
}

Something called the 'half-caste problem' was noted in many colonial situations during the interwar period. Numerous books and chapters addressed it. ${ }^{2}$ At least one global survey was attempted (Dover 1937). Half-castes also figured in fiction, images, and song. Noel Coward, better known for 'Mad Dogs and Englishmen', sang a ballad 'Half-caste Woman' which I listened to from an old record as a child. ${ }^{3}$ Later, during the course of research that was not particularly concerned with miscegenation, I was struck by contrasting attitudes towards half-castes in several locations in the southwest Pacific during these decades. Two questions puzzled me. First, why, in New Zealand, was indigenous and European miscegenation actually celebrated by some proponents while advocates of a parallel process in Australia were less than jubilant? Second, why did New Zealand administrators revile and vituperate half-castes in Western Samoa when politicians and officials back home rejoiced in their nation's outstanding men of mixed race? While these views on half-castes were not universally held in their time and place, they were nevertheless prominent and I wondered how their differences could be explained. The following discussion is my attempt to do so.

I begin by reviewing the ancestry of the term 'half-caste', comment on the 'half-caste problem' between the wars, and outline some very general variants - in time, space, and racial reasoning — that can help explain the contrasting evaluations of miscegenation to which my opening questions refer. I then turn to the three main sites of this inquiry - Australia, New Zealand, and Western Samoa — while also drawing some illustrations from Australia's mandated territory of New Guinea and the British Crown Colony of Fiji. Although writing for a volume devoted to the science of race, I remain uncertain as to how the science of race can be defined in these locations and how its influence on policy and action can be tracked and measured. ${ }^{4}$ Instead, I suggest some differences in broad patterns of racial thinking relating to half-castes and correlate them 
with the differences between the imperatives of 'settler' and 'managerial' colonialisms, at least in this quarter of the world - imperatives which were in turn determined to a considerable degree by environment. Though I have no qualms about alluding to environmental influences upon colonial formations, in conclusion I mention some of the difficulties in proposing the 'imperatives' that I outline as historical explanations, despite the fact that my own efforts have led me to them. These difficulties raise questions that remain unanswered as I finally reflect on the postcolonial fortunes of the term half-caste.

\section{The half-caste}

The word half-caste has an imperial genealogy going back to the Roman Empire, which exported the Latin adjective castus, 'pure', 'unpolluted', to its subjects. From these origins, modern English derives 'chaste' but half-caste was a later child of linguistic miscegenation between the empires of Portugal and Britain. In Portuguese, the adjective casta in the phrase casta raça, 'pure race', was nominalized and from the mid-sixteenth century came to denote the large endogamous groupings of India. ${ }^{5}$ The English adapted this Portuguese term and from the late-eighteenth century, in order perhaps to differentiate this specialized sense from all the meanings associated with the homonym 'cast' (the verb of non-Latinate derivation meaning 'to throw'), began spelling 'caste' with a final 'e'. Simultaneously, the term half-caste appeared. Referring to persons of combined European and Indian parentage, it coincided with the introduction of employment policies in the British East India Company that discriminated against men of mixed race. From the start, half-caste had pejorative connotations. It also appealed to what the British understood as 'Indian notions of birth', with the concept of caste, more so than race, entailing injunctions of physical, sexual, and marital exclusiveness (Ballhatchet 1980:4, 97-8). With the expansion of Britain's empire, half-caste was applied loosely to any person of mixed race.

\section{The 'half-caste problem' between the wars}

Several factors appear to have contributed to the interwar prominence of the 'half-caste problem'. First, ideologies of race were perhaps most widely popularized and implemented by governments during these years - even though the intellectual bases of racial science were already under assault in Britain and the United States (Barkan 1992). Half-castes were significant because they affronted ideals of racial purity and challenged the real or imagined structures, including colonial structures, founded thereon.

Second, many colonial rulers were now keenly feeling the vulnerability of empire to moral objection and coloured revolt. As one former British Under-Secretary of State for the Colonies remarked, a wave of restlessness had swept the world since the Great War (Shiels 1933:321). In tropical possessions, wherever Europeans constituted managerial minorities, the question of where 
to place and how to treat the mixed-blood descendants of the ruling race was, in theory and practice, often problematic. Where the male half-caste was spurned by his father's people, they sometimes feared him as, metaphorically, a potential parricide. This spurning was painfully true of the British imperial tradition though, as will be seen, there were exceptions, and the stereotypes which characterize French, Spanish, Portuguese, and Dutch colonialisms as more accepting of racial mixing do not entirely survive scrutiny. ${ }^{6}$ The half-caste woman was depicted as dangerous in a different way: she was tragically alluring, for in tempting a white man to marry she could bring him, it was often said, to social and racial ruin. ${ }^{7}$

Third, half-castes were in effect metonyms for interracial sex. Male or female, they were its proof and product. If female, from a white man's viewpoint they were often seen to invite it. The accentuated sensitivity to racial divisions in these years therefore only served further to eroticize in the European imagination those who appeared to embody the sexual transgression of these divides. In societies of mass European settlement with indigenous minorities, such as Australia and New Zealand, the half-caste was perhaps not feared as such a potentially violent threat and was perhaps less eroticized. But here, too, 'the half-caste problem' was symbolically charged and complicated the process envisaged for shaping a national identity. ${ }^{8}$

\section{Differing evaluations of miscegenation}

I suggest three general axes of variation to help explain the different evaluations of miscegenation that this chapter will address. The first is chronological. The conditions of frontier, as distinct from later colonialism often conduced to the acceptance of interracial liaisons and their offspring. This initially relaxed attitude to interracial sexual relations was partly a matter of sexual pragmatics since white women were usually scarce on the frontier. It could be partly strategic, since liaisons with local women could help white men gain useful knowledge and relationships. The children born of these unions, especially if their fathers or paternal associates cared for them, often became entrepreneurs in the frontier economies.

The photographs in Figures 19 and 20 - the first of a white father and the second of an indigenous mother and their son - illustrate certain significant features of frontier miscegenation. The son, Clem Leahy, was one of three mixed-race half-brothers by the same father, Michael Leahy, who led the first European expeditions into the New Guinea highlands during the 1930s and met Clem's mother, Yamka Amp Wenta, in the Mt Hagen area when she was sent to him by her husband. Though Michael Leahy did not acknowledge his children by local women, missionaries targeted his sons. All three were schooled by Christian missions and became successful businessmen. ${ }^{9}$ 
Figure 19: Anon., 'Michael Leahy in the Wahgi Valley, 1934'. ${ }^{10}$

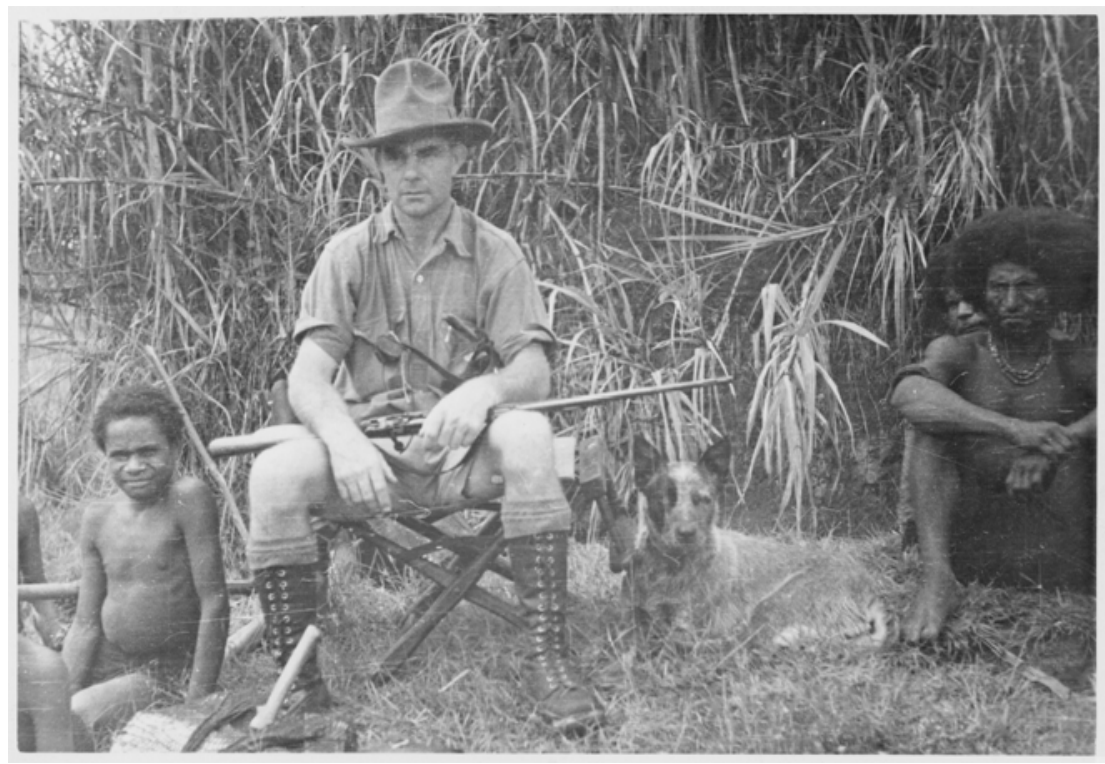

Photograph. nla.pic-vn4198892. Canberra: National Library of Australia.

Figure 20: Robin Anderson, 'Clem Leahy and his Mother, Yamka Amp Wenta, 1983'. ${ }^{11}$

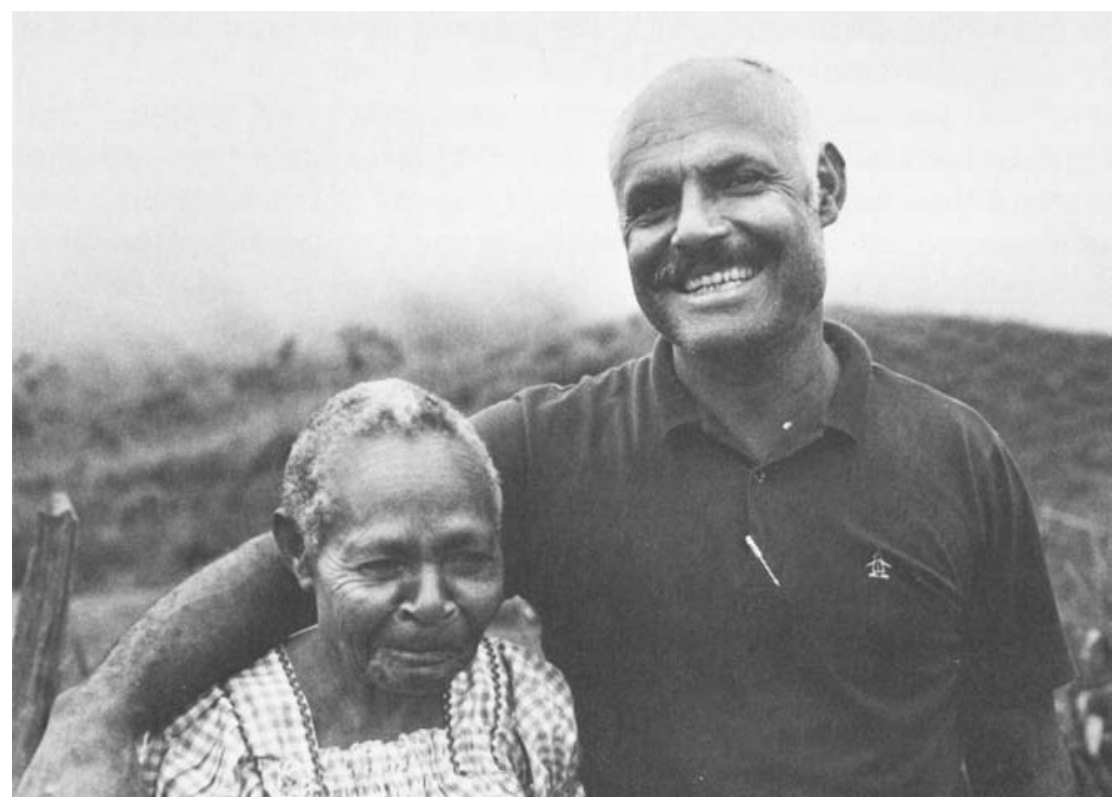

Photograph. (C Robert Connolly and Penguin Group. Photograph B. Douglas. 
More fundamentally, the parents in these photographs display the archetypically gendered ancestry of the European half-caste: father white, mother coloured. ${ }^{12}$ There were of course cases - usually later - in which the mother was white and the father coloured but this occurrence was relatively rare and such sexual relations aroused hostility in European, especially male European, observers. Fernando Henriques (1974:78-92), in his classic survey of miscegenation beautifully entitled Children of Caliban, explored this antagonism. It was the subject of Amirah Inglis's (1975) examination of the White Women's Protection Ordinance in Papua. Claudia Knapman (1986:113-35) analyzed it in her study of white women in Fiji. Ann McGrath (1987:73) discussed it too in the 'cattle country' of Australia's Northern Territory. The most vivid cameos from my archival research relate to the nineteenth century. In Fiji in 1892, the white widow of a Colonial Sugar Refinery employee was living as wife with a Fijian chief. The administration denied him chiefly honours and the disgust of white officials is almost palpable on the page: 'The case is bad as it is'. ${ }^{13}$ Still earlier, an elderly white woman who granted intercourse to Fijians for a small fee caused intense official indignation. She was deported. ${ }^{14}$

The photographs make a further chronological point. In many parts of Melanesia, such as the New Guinea highlands, empire was just beginning at or near the close of the imperial era. A map of Australia by the entomologist turned anthropologist Norman B. Tindale (1900-1993) traces further such examples. ${ }^{15}$ During the decades following World War I, Australian frontiers were still advancing in the continent's north and centre and these areas were also the zone of first generation half-castes. But time cannot always be so neatly mapped. Different times may coexist. Elements of the culture of frontier can survive into later periods. As John Owens (1992:53) commented, 'Old New Zealand' romanticized by some as the 'good old days' of the Pakeha-Maori, a term referring to Pakeha, 'Europeans', who 'went native' — continued in remoter areas. These social survivals combined with persisting values and memories derived from an earlier era to nourish, even to the present, an alternative tradition of race relations in New Zealand. A similar statement could be made for all the countries discussed here.

My second axis of variation is latitudinal. Throughout the colonial era and into the twentieth century, Europeans tried to explain the apparent toxicity, to them, of the tropics where they tended to sicken and die (Curtin 1990:136-8). One theory, not so very far from Alfred Crosby's (1986) classic explanation of the ecological determinants of European expansion, was that Europeans were constitutionally ill-suited to tropical climates. If the tropics were bad for white men, they were believed to be worse for white women. Aside from the usual scarcity of white women in such locations, these beliefs supported arguments in favour of interracial liaisons and also strengthened the case for hybrid progeny. 
For European enterprise in the tropics, half-castes could inherit from their fathers a loyalty, training, and taste for the activities of empire and from their mother - aside from contacts and local knowledge — acclimatization to their surroundings. These considerations probably influenced the vision splendid of one Wesleyan missionary in the 1840s, Walter Lawry (1739-1859), who looked forward to the day when a proud race of industrious Christians, descended from native mothers and white fathers, would populate the isles of the Pacific (1850:135). ${ }^{16}$

Beliefs in the toxicity of the tropics continued, however, into the interwar era. In Australia, though doctors like Raphael Cilento (1893-1985) — who liked to walk in the tropical sun without a hat - proclaimed that medical conquests, if combined with stringent racial segregation and sanitary discipline, now enabled white settlement of the nation's north, some expert and much popular opinion was less certain. ${ }^{17}$ These doubts still supported certain arguments in favour of miscegenation. Thus Cecil Cook (1897-?), from 1927 Chief Medical Officer and Chief Protector of Aborigines in the Northern Territory, buttressed his case for marriage between mixed-race women and white men by saying that their children would derive, through their mothers, biological protection against skin cancer (a condition, incidentally, that plagued Cilento!). ${ }^{18}$

Associated with the idea of the toxicity of the tropics was the common contrast between temperate and tropical forms of colonization. Temperate regions were usually environmentally benign to Europeans and what Crosby (1986) calls their 'portmanteau biota' which included their associated plants and animals. Tropical colonies, however, were ecologically less hospitable to this European package. Broadly, different demographic histories and patterns of race relations correlate with these environmental differences. In the first, precipitous indigenous population decline, due to sickness, dispossession, and violence, was often accompanied by heavy European immigration, conflict over land, and troubled political relations between the indigenous minority and European majority in the subsequent evolution of a new, shared nation. In the second, whether or not the indigenous people were susceptible to introduced diseases, white populations rarely took deep root or abundantly flourished. Typically they amounted to no more than a minority who held managerial positions in administration, business, and the Christian missions. There was no comparable 'demographic takeover' (Crosby 1994:29-31). ${ }^{19}$

My third axis of variation is along a particular line of racial logic that sometimes favoured half-castes and sometimes not. The characterization of half-castes as infertile, prone to illness, lacking vitality, and combining the worst elements of both parental lines was commonplace. But derogatory assessments often coexisted with enthusiastic appraisals. ${ }^{20}$ For example, in a lengthy official report into the reasons for the decrease of the indigenous Fijian population, 
published in 1896 and revived and feted between the wars, negative statements about half-castes can be read alongside arguments strongly in favour of racial mixing. The authors - all civil servants - were for instance keen to import Barbadians to interbreed with Fijians in order to produce a robust new racial hybrid (Stewart et al. 1896:184-7). One of these authors, Basil Thomson (1861-1939), like innumerable English writers since Defoe, also gloried in the mongrel vigour of the British. ${ }^{21}$ How can these apparently divergent assessments of miscegenation be reconciled?

Here the concept of racial distance is pivotal and can be illustrated by reference to animal breeding. The examples of the mule and the racehorse were often invoked. The mule was an age-old symbol of hybridization (and hence the term 'mulatto' for persons of mixed European and Negro ancestry). ${ }^{22}$ It supposedly demonstrated the law that strains too far removed from one another mated unnaturally and produced defective offspring. The main defect of the mule was infertility. The racehorse, however, showed that by crossing distinctive but related strains and carefully mating their offspring in ensuing generations, a magnificent new breed could be produced (Pitt-Rivers 1927:6, 97). Of course, we could argue with such evaluations (what about, for instance, the virtues of a mule or the deficiencies of a racehorse?), but the influence of models drawn from animal breeding and horticulture was profound in both lay and specialist thinking about half-castes. ${ }^{23}$

For human miscegenation, the lesson usually drawn was therefore that crosses between races regarded as sufficiently close to one another were likely to prove beneficial while those between races considered too distant would not (e.g., Broca 1864:16-66). The historian Stephen Henry Roberts (1901-1971) clearly applied this principle in a chapter on race mixing in the Pacific (1927:352-86). He acknowledged the old prejudice that all hybrids invariably combined the worst features of both parents. He acknowledged some experts who condemned even crossing closely related races. He also admitted the great diversity of opinion on all matters relating to race - including the repudiation of race as an entity. But Roberts did nevertheless confidently confirm this rule of racial distance. Thus, on the basis that Polynesians and Micronesians were deemed to be relatively close to Europeans and 'Asiatics', their mixture with European or Asian strains could be approved. Melanesians, however, were too distant from either Europeans or 'Asiatics' in Roberts' racial schema to be profitably combined with either. Roberts made no mention of Aborigines. Since a consensus of both expert and popular opinion had characterized the indigenous people of Australia as among the most primitive on earth, ${ }^{24}$ the rule of racial distance did not favour the results of Aboriginal miscegenation with so-called higher races. But, as we shall see, racial distance was elastic. 


\section{The 'half-caste problem' in Australia}

Australia and New Zealand were colonies of mass-European settlement. In both, the status and future of their indigenous minorities complicated the ideal and attainment of nationhood. As McGregor (1993:57) observed in relation to Australia, the belief that national cohesion depended upon 'a large degree of racial homogeneity' - displayed and symbolized in 'whiteness' — was standard. During the interwar period, among white New Zealanders particularly, similar values and metaphors resonated and scholars have explored the significance of 'whiteness' for both nations. ${ }^{25}$ Though Belich has argued that a more appropriate descriptor of New Zealand's racial template was 'Aryan' rather than 'white', the quest for racial consistency provides a common ground for considering approaches to miscegenation on both sides of the Tasman in the era examined here.

In Australia between the wars, the half-caste problem was most vividly perceived on the frontier where the children of Aboriginal mothers and European fathers were often described as destitute. Paul Hasluck (1905-1993), later Minister for Territories, said that most had 'no chance to be anything but hangers-on' (1938:3-4). The historian Gordon Briscoe (2001), who was born at a native institution in Alice Springs in the late 1930s, has described how Aboriginal mothers living near the transport and communication links of central Australia survived under great stress, without support from the white fathers of their children but also reluctant to live a tribal life and fearing tribal men. Unusually severe droughts in Central Australia during the 1920s also compelled many people of Aboriginal descent to depend more heavily on support than before. The Great Depression then denied incomes to many who had been earning money. ${ }^{26}$ Demographic trends were also apparently dramatic. Population data were unreliable but seemed to show that half-caste numbers had steeply increased. ${ }^{27}$ To some observers, half-castes promised either to form an ever-growing, impoverished, illiterate, coloured population or, alternatively, to merge back with 'full-blood' Aborigines and swell their numbers (Briscoe 2001; Hasluck 1938:6).

At a conference held in Canberra from 21-23 April 1937, Commonwealth and State Aboriginal authorities addressed the half-caste problem. It resolved that 'the destiny of the natives of aboriginal origins, but not the full-blood, lies in their ultimate absorption by the people of the Commonwealth, and it therefore recommends that all efforts be directed to that end'. ${ }^{28}$ Tindale (1941), following a survey of Australia's half-caste populations conducted in 1938 and 1939, ultimately agreed. He rhetorically posed four options. The sterilization of half-castes he immediately dismissed. He also rejected the desirability of cultivating a new but distinct half-caste race - though in a few circumscribed communities he saw the process under way and some missionary opinion 
supported the idea (e.g., Webb n.d.). Tindale considered current policies, characterized by inconsistency and drift, as undesirable too. ${ }^{29}$ Assimilation through miscegenation, which required the removal of mixed-race children, was the remaining option. Within government circles, Cook in the Northern Territory and A.O. Neville (1874-1954), the Commissioner of Native Affairs for Western Australia, were the most energetic proponents of this policy which gained increasing favour in the late 1930s (Wilson 1997:32-5).

More than one motive or justification can be discerned in the policy of child removal. Certainly, the image of half-castes as destitute and outcast often misrepresented their situation. Even among those in difficult circumstances, there is piercing testimony to the strength of caring ties that connected persons of mixed ancestry with parents and kin - whether white, 'full-blood', or within evolving half-caste communities. ${ }^{30}$ The vital contribution of Aboriginal and mixed-race men and women to the rural economy was also widely admitted. J.W. Bleakley (1879-1957), the Chief Protector of Aborigines in Queensland, remarked in an official report that the pastoral industry in the Northern Territory was 'absolutely dependent' upon them (1929:7; McGrath 1987). Others referred to half-caste families 'owning their own property, paying rates, educating their children, managing their affairs', and functioning within white society, if a modest grade (Hasluck 1938:23). Some alluded too to half-castes of high social status within white society, such as the landowning '5/8 Aboriginal of wealth, married to a white woman' whose class was inferior to her husband's (Tindale 1941:113, 119). Nevertheless, the removal of mixed-race children harmonized with the established practice of institutionalizing children deemed neglected or deprived.

Measures to remove mixed-race children were not confined to Australia. Indigenous writers of New Zealand and Canada have discovered similar histories of child removal. ${ }^{31}$ In managerial colonies, too, Europeans were often averse to the sight of light-skinned children growing up 'native'. In the Australian mandate of New Guinea, indigenous parents hid their 'white' children from missionaries and others in authority and some coercion was used to remove Clem Leahy and his half-brothers from their families for missionary schooling. ${ }^{32}$ Occasional files in the colonial archives of Fiji also concern the removal of 'white' children from indigenous communities. The Methodist missionary Joseph Waterhouse (1828-1881), for instance, appealed for the removal of two white boys from Fijian households, insisting that these children should have 'the education and advantages common to those of their colour'. Even before colonial rule in these islands, he remarked, half-caste families never allowed their children to live with Fijians. $^{33}$

Clearly, then, some white onlookers within and beyond Australia objected to the exclusion of such children from their paternal heritage and believed that 
church or state should assume a responsibility for them, as an uncle might acknowledge the offspring of an errant brother by adopting the role of father. These are complicated feelings in which arguably emotions and ideas about kinship, paternal responsibility, and rights of inheritance were translated into a discourse on race. But at a certain level of interpretation, the teleological force of the vision of a 'white Australia' seems difficult to deny. 'Full-blooded' Aborigines were not such an issue. Whether they totally died out, as many commentators still believed they would, or whether small populations could survive inviolate under secluded conditions, made little difference to this vision. ${ }^{34}$ Half-castes, however, had to be a transitional category for the goal of white Australia to be reached.

Yet two basic difficulties bedevilled this long-range process. First, it relied on the intermarriage of half-caste women with European men but left unanswered the question of what to do with half-caste men (McGregor 1997:167-8). The second difficulty related to the supposed racial distance between Aborigines and Europeans. A policy favouring marriage between half-caste women and white men had, in effect, to shorten that distance. Advocates of such a policy tried to do precisely this. They insisted that no harmful effects of Aboriginal ancestry could be discerned in the children resulting from intermarriage with whites: unlike 'Negro blood' which allegedly produced occasional 'throwbacks' to the Negro-type among white descendants, 'Aboriginal blood' disappeared after a few generations. Indeed, Neville (1947:63) averred that among whites and Aborigines, the opposite kind of 'throwback' occurred, with a child of an Aboriginal mother sometimes reverting to the colour of a white grandfather. Moreover, increasing stress appears to have been laid on racially classifying Aborigines as 'Caucasian'. ${ }^{35}$ The geographer Griffith Taylor (1880-1963) joined a chorus repeating that 'blood-tests of Australian aborigines agree more closely with those of west Europeans than with similar tests of most intervening races' ${ }^{36}$ Thus, with assurances rather than celebration, the racial distance between Europeans and Aborigines was narrowed.

\section{Half-castes in New Zealand: not a problem?}

In New Zealand, however, the biological amalgamation of Maori and European sent some commentators into transports of eugenic delight. Of the various theories of Maori origins propounded during the nineteenth and early twentieth centuries, that proposing their Aryan origin informed much thinking in the interwar era and, like the Caucasian Aborigine, brought indigenes and whites racially closer in the settler imagination. ${ }^{37}$ To combine and paraphrase a few texts from that time: the Maori, our distant relatives, are manly and the bravest and most intelligent of the Polynesians; after the long voyage to New Zealand, which only fine human specimens would undertake or survive, subsequent generations were invigorated, intellectually and physically, by the bracing climate; just as 
Maori represent the best of their race, so white New Zealanders are the best of the British (better than those left behind - and infinitely superior to Australians). Thus, in New Zealand the superb blood of two fine peoples mixed. ${ }^{38}$

Proponents of these views were not all European. At least one eulogist was of mixed Maori and Pakeha ancestry. Peter Buck (c. 1877-1951) was a doctor, politician, and ethnologist, later knighted and also known as Te Rangi Hiroa. He recalled his horror, as a student, reading a sign in the Otago Medical School advertising Maori skulls, pelves, and skeletons for sale, and yet subsequently devoted much of his professional energy to Maori somatology. ${ }^{39}$ In later life, he directed the Bernice P. Bishop Museum in Honolulu and when he died, Sorrenson (1973:193) recalled, New Zealand's 'politicians vied with one another to bring back his ashes'. As one of a group of outstanding men of Maori parentage — including Sir James Carroll (1857-1926), Sir Maui Pomare (1876-1930), and Sir Apirana Ngata (1874-1950) — Te Rangi Hiroa was a national trophy, displaying the unique triumph of race relations in New Zealand. One patriot remarked that these men 'would grace any gathering of any race or any nation' (Nash 1927:36). Several could have been called 'half-castes' but that appellation appears to have been rarely, if ever, applied. Notwithstanding their mixed race, Pakeha often celebrated them as Maori. ${ }^{40}$

Following the 'Aryan' tradition, Te Rangi Hiroa supposed an original homeland for the Polynesians in northern India. During their subsequent travels, he believed $(1938: 8,25)$, they were infused with the blood of other races but remained fundamentally Europoid (or Caucasian). In an earlier essay (1924:365, 369), he described how New Zealand had changed those Polynesians who had landed there. For five centuries, 'the temperate climate had toughened ... [the] constitution of the Maori, sharpened his mentality, and altered his material culture'. This evolutionary process set Maori apart from tropical Polynesians. And, after weathering 'the storm of extinction' that followed European settlement, Maori numbers had recovered. From their nadir in 1871, when there were an estimated 37,520 Maori, by 1921 they had increased to 52,751.

But Te Rangi Hiroa did not believe that Maori would survive as a distinct race. Their future was intermixture and absorption. The fate of Maori in New Zealand's South Island seemed already to endorse this prediction. By the end of the nineteenth century, so rapid and far-reaching had been the effects of miscegenation and cultural assimilation that - according to the prehistorian Atholl Anderson (1991:31), himself a product of this history - very few descendants of South Island Maori culturally identified with Maoridom (though this is not the case today). Te Rangi Hiroa (1924:371) argued that neither white New Zealanders nor Maori could object to 'another intermixture' since each side 'was long ago deprived of any pretensions to purity of race'. 'Miscegenation', he continued (1924:374), 'has stepped in, as it has all down the ages'. He challenged 
the earlier, much cited pontifications of Alfred Kingcome Newman (1849-1924), a medical doctor and businessman, who had predicted (1881:50, 475-6): 'In the course of a few generations the Maoris will die out and leave no trace of their union with the whites'. Instead, Te Rangi Hiroa (1924:371) argued that Maori would shape 'the evolution of a future type of New Zealander in which the best features of the Maori race will be perpetuated for ever'. ${ }^{41}$

Favourable evaluations of Maori and Pakeha miscegenation, the way in which national figures like Te Rangi Hiroa seemed to demonstrate its attractiveness, and the distinctive features of race relations in New Zealand deserve more consideration than can be given here. Until the 1970s, white New Zealanders continued to take pride in what they saw as their unique success with Maori. As late as 1971, the historian Keith Sinclair (1971:125-7) wrote a short piece entitled 'Why are race relations in New Zealand better than in South Africa, South Australia or South Dakota?', particularly stressing the special influence of Christian and humanitarian ideals. A few years later, the historian Kerry Howe's (1977) study of race relations in New Zealand and Australia acknowledged ideological factors but qualified their importance, referring to environmental determinants in an argument to which my discussion will return. For most New Zealand historians of the last three decades, however, Sinclair's question might seem to validate a self-congratulatory assumption that they have energetically repudiated. No longer is New Zealand projected as an exception to the sorry history of settler colonialism but, as historian Claudia Orange (1987:5) remarked, a variation on the general pattern. ${ }^{42}$

\section{The menace of the half-caste in Western Samoa and Fiji}

I now shift from settler to tropical empire in order to reflect upon the contrast between New Zealand's domestic eulogizing of miscegenation and the tirades directed against half-castes in New Zealand's territory of Western Samoa. In 1914, New Zealand troops seized these islands from Germany and the League of Nations granted New Zealand the mandate after the War. New Zealanders were qualified for this administrative role, according to some spokesmen, because their record with Maori had demonstrated a gift for administering Polynesians (Cocker 1927:37). Yet some New Zealanders' attitudes to and treatment of half-castes in Western Samoa indicate a very different set of racial logics and imperatives. $^{43}$

Though my ultimate destination is Western Samoa, I stop en route in Fiji, as was normal for passengers travelling by sea from Auckland to Apia. As sites of broadly similar tropical or managerial colonialism, Fiji and Western Samoa shared certain characteristics. The largest component of their populations was indigenous (though in Fiji, the Indian population, descended mostly from indentured labourers, was growing rapidly and would outnumber indigenous Fijians by 
the census of 1946). Europeans were a minority. Those Europeans born and raised in Fiji and Samoa included men and women of mixed race who were classed as Europeans, usually through a legally recognized European patriline. ${ }^{44}$ The colonial administrations of Fiji and Western Samoa adhered similarly to the principle of the primacy of native interests. This was the proclaimed moral basis of the British administration in Fiji. The German administration of Western Samoa, which New Zealand inherited, had also subscribed to this ideal. After World War I, an ethic of modern, imperial responsibility, explicitly promoted by the League of Nations, endorsed it too. This principle needed, of course, a prior definition of the 'native' which tended to rely heavily on racial terminology. Between the wars, the principle of native primacy coexisted with a process whereby the categories race and class appear, in the anglophone managerial tradition of empire manifested in these colonies, to have been congealing into functional colonial castes.

This process was very marked in Fiji and contributed to the indignation some British officials felt towards European tourists disembarking from visiting ships during the twenties and thirties. ${ }^{45}$ The relaxed behaviour of these white tourists and their friendliness with Fijians in the streets flouted the rules of social distance that expressed the division of the races. In Fiji's hierarchy of colour, Europeans were on top, with indigenous Fijians beneath them, and Indians at the bottom. The role of Europeans was to rule. The role of Fijians was simply to exist and reflect well on the administration by thriving and in some ways modernizing. ${ }^{46}$ The role of Indians was to underpin the sugar industry through their labour. Race, for this colony, was an organizing principle, an identifier, and a value. ${ }^{47}$ But as the discomfort caused by white tourists to some officials shows, this racial schema had difficulty accommodating people whose behaviour or colour did not fit the prescribed categories. While the political and economic aspirations of Indians posed the greatest challenge to Fiji's racial hierarchy, half-castes were threatening too. Those (of white, Chinese, Indian, or any other ancestry) reared as Fijians were controversial and offensive to the ideal of racial purity (Lukere 1997:211-34). But half-castes who were classed for legal purposes as Europeans were a problem felt even more keenly by the administration.

Much class differentiation could be found within this mixed-race category. The course of Fiji's colonial development had reduced opportunities for such people and most half-castes classed as Europeans were poor. White, expatriate managerial elites in the 1920s and 1930s increasingly rejected them. ${ }^{48}$ The dominant ethnic Fijian in administrative circles, Ratu Sir Lala Sukuna (1888-1958), described the problem thus: half-castes wanted greater political involvement but their educational level was little higher than that of Fijians. Socially rejected by Europeans and Fijians, 'they are easily carried away by appeals based on notions of equality'. Their numbers were rapidly increasing and they would 
soon swamp the vote of true whites: 'At no distant day the European electorate', said Sukuna (1983:176), 'will be white only in name, enlightened only in memory'. With its founding creed of native welfare, the administration had real difficulty with the political aspirations of those subjects who were racially excluded from the core relationship between indigene and ruler.

New Zealand interpreted the League of Nations mandate as placing Samoans in its sacred trust. ${ }^{49}$ For the New Zealand administration, the category 'Samoan' did not include half-castes of Samoan ancestry who were classed as Europeans. In 1930, out of Western Samoa's total population of 40,722, persons of mixed descent classified as Europeans numbered roughly 2,320 (Keesing 1934:32). ${ }^{50}$ As in Fiji, they were increasing rapidly and even greater class differentiation obtained among them. The majority were poor, landless, culturally closer to Samoans than Europeans, but proud of their European status. A minority were affluent. Unlike Fiji and also unlike American Samoa, Western Samoa had supported a comparatively large, nationally diverse European community numbering some 600 individuals in $1914 .^{51}$ Intermarriage was common between Samoan women and white men with longstanding business interests in the islands. Germany's relatively late imposition of effective colonial government in 1899 had prolonged the experience of a frontier ethic that was more accepting of interracial liaisons and no doubt helped to promote the exuberance of the mixed-race commercial community. ${ }^{52}$ In the 1920s, Keesing (1934:461) observed that many of the older white men were dying off and nearly 200 Germans had left the territory. Consequently, children of mixed descent were inheriting family property and business. Many had been educated as Europeans but also participated in networks of Samoan kin. Indeed, there was sometimes economic advantage in their doing so. Such men, Keesing noted, lived 'in both mental worlds and know both moralities'. They occupied positions of considerable commercial and political influence.

New Zealand officials found both poor and well-off half-castes classed as 'Europeans' difficult. Regarding the former, one high official explained: 'It would not be fair to the Samoan in whose interests the islands are governed and the preservation of whose race is considered to be our duty, to give the half-caste the same status as the native with regard to the land ... the half-caste must be left to sink to his level in the scale of humanity' (quoted in Keesing 1934:463). 'Europeans' who enjoyed traditional Samoan titles and use of Samoan land through their maternal kin were blocked from converting that land to freehold and were discouraged from exercising the political power associated with their titles. To represent Samoans in the Legislative Council, these 'Europeans' were required to abandon their European legal status and surrender associated rights, which none was keen to do (Meleisea 1987:171). Men of mixed race were also excluded from employment in government service. 
Despite and perhaps partly because of New Zealand's zeal to run a model mandate primarily for the benefit of 'pure' Samoans, local Europeans, including prominent half-castes classed as Europeans, ganged up with other leading Samoans against the administration. The resulting mass Samoan movement of non-cooperation, the Mau, disabled New Zealand rule for several years in the late 1920s and early 1930s. The death of high chief Tupua Tamasese Leolofi after he was shot by New Zealand police at a peaceful demonstration of the Mau on 'Black Saturday', 28 December 1929, became a sombre symbol for Samoan nationalists of their people's resistance to colonial domination and their quest for political independence.

However, many contemporary European observers instead viewed the Mau in terms of the menace of the half-caste. The Mau was often described, especially in the early days, as a half-caste movement that lacked real Samoan support for Samoans, so officials believed at the outset, did not like half-castes. ${ }^{53}$ Demonstrations by the women's Mau were wont to be dismissed by officials as the actions of a rag-bag of half-caste women accompanied by well-known damsels of loose morals. ${ }^{54}$ Many saw O.F. Nelson (1883-1944), a mixed-race businessman of girth, wealth, and intellect who also commanded high traditional status among Samoans, as the root cause of the trouble (see Figure 21). ${ }^{55}$ When he and others were exiled to New Zealand, supporters of the Mau demanded to know why, if mixed-race men of Maori mothers were accepted as Maori leaders, the government rejected mixed-race men of Samoan mothers as leaders of Samoans (Anon. 1929). The official language vilifying Samoan half-castes - alleging their perfidy and cunning, their desire to oust European officials, their exploitation of naïve indigenous Samoans, the deplorable fact that so little British blood flowed in their veins (Nelson had none while German blood was said to vitiate most Samoan 'Europeans') - and the proposal, before the Mau came to a head, to solve the half-caste problem in the territory by exporting them all to New Zealand, demonstrate a striking difference between New Zealand's domestic and external racial lexicon and manners. ${ }^{56}$ 
Figure 21: Anon., 'Samoan Patriots'. ${ }^{57}$

\section{||Samoan Patriots}

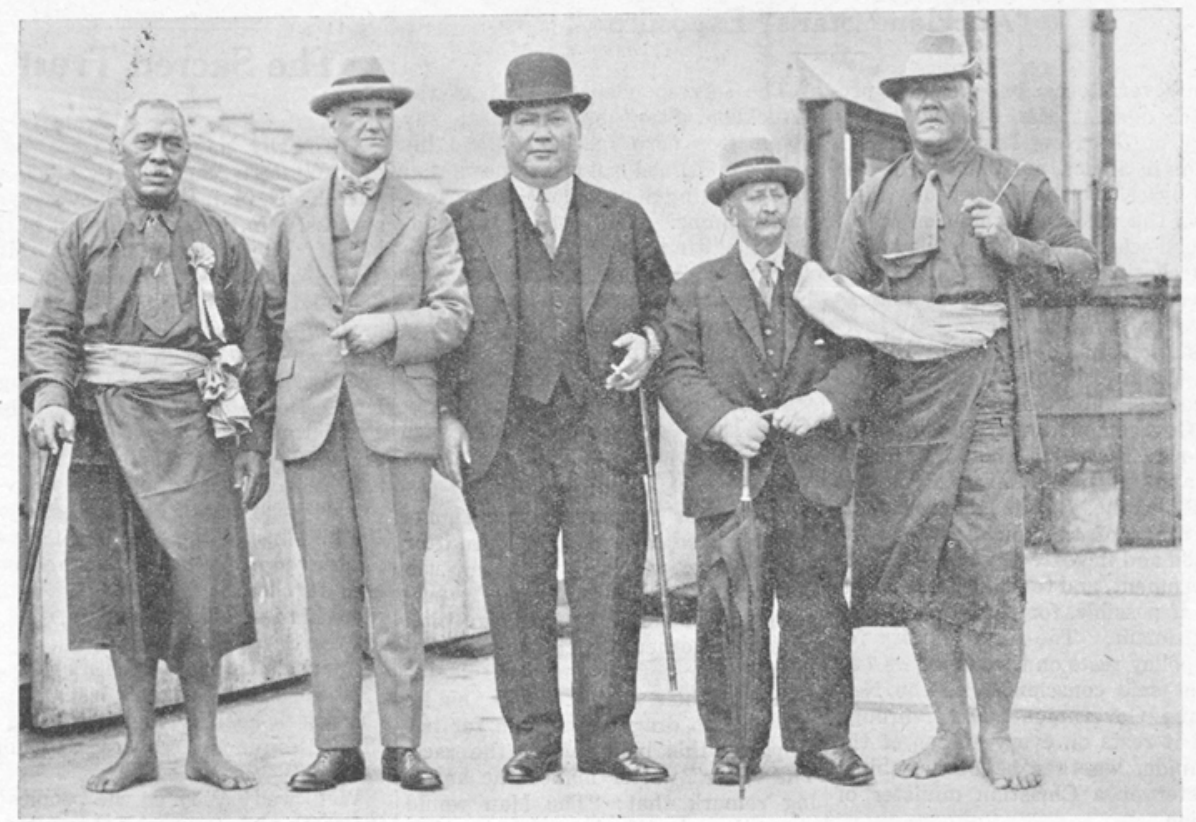

(From reader's left to right): High Chief Tuimalealiifano, Mr. A. G. Smythe, Hon. O. F. Nelson, Mr. E. W. Gurr, and High Chief Faumuina.

Photograph. JAF Newspaper 079.9614NZS, Canberra: National Library of Australia.

\section{The significance of place}

The administration's handling of the Mau caused outcry and controversy in New Zealand. Many commentators found it difficult to explain why half-castes in this island territory had proven so problematic. The psychologist and ethnologist Ernest Beaglehole (1906-1965) later reflected that perhaps the legacy of earlier German attitudes towards Samoan half-castes was somehow to blame $(1949: 56-7) .{ }^{58}$

But the attractiveness and assimilability of the Maori half-caste, in the lines of thought described in this chapter, and the contrasting indigestibility of the Samoan half-caste perhaps derived in part from differences in broad colonial requirements. During this era in the settler societies of Australia and New Zealand, to achieve the goal of a racially coherent nation that was some shade of white, indigenous elements had logically to be absorbed into the majority population. Despite New Zealand's founding Treaty of Waitangi — which authorized the coexistence of two distinct peoples and two ways of life, one indigenous and one European — Te Rangi Hiroa and like-minded thinkers in New Zealand shared with the advocates of intermarriage between half-castes 
and whites in Australia a similar national vision and ideal of racial homogenization - even if in New Zealand they saw it as a more distant goal. By contrast, managerial colonialism in Samoa and Fiji required service to the ideal of native preservation. Fiji was in principle for Fijians, Samoa in principle for Samoans. The performance of social roles as conceived in these colonies relied on the language of race for the definition of their agents. This was a political vision - and ideal - of racial differentiation.

These statements of contrasting racial ideals and imperatives, though big, loose, and abstracted, nevertheless remind us that place is more than an historical site: it can be an historical actor too. At least one Maori observer of New Zealand's troubles in its territory of Western Samoa sensed this. The barrister and parliamentarian Sir Apirana Ngata stressed the radically different nature of the race relations necessitated by mass white settlement in his ancestral lands, gently challenging the conceit that white New Zealanders' colonial record with Maori fitted them to administer Samoans and also underscoring the more profound upheaval that his own people had had to survive. If Western Samoa, he wryly remarked, had been a temperate country suitable for European settlement, then the motto 'Samoa for Samoans' - first coined by the New Zealand administration though the Mau appropriated it - would have justified the taking of land from Samoans as in the Samoans' best interest. ${ }^{59}$ In terms of my initial three axes of variation, Ngata seemed to see the latitudinal as ultimately the most important determinant of colonial racial ideology. And while I argue that the particular attitudes towards miscegenation in Australia and New Zealand that have been addressed here share fundamental similarities, their contrast - measured in differing degrees of enthusiasm for the biological absorption of indigenous elements within the white majority - can also be explored, as Howe has argued (1977), in terms of comparative colonial histories ultimately and crucially shaped by place.

Yet while this chapter has tried to give an answer to the opening questions, even within these terms of reference I am uneasy with my conclusions. In Australia's case, for instance, just how important was a teleology of a white Australia? I feel its undertow and some of the writers cited here stress its power. Patrick Wolfe $(2001 ;$ 1999:32) talked in language stronger than mine of a 'logic of elimination' that corresponded with settler colonialism and he dubbed Australia's policy of biological assimilation a 'eugenic realpolitik'. But even if we concede this teleology, the removal of mixed-race children could occur without it; some individuals who aspired to a white Australia did not support a policy of 'breeding out the colour'; while a few in favour of racial mixing rejected this national ideal as unattainable. I have previously alluded to examples of the removal - or attempted removal - of mixed-race children in the mandated territory of New Guinea and colonial Fiji where no logic of absorption towards the telos of white nationhood pertained. Leading promoters in Australia of 
'breeding out the colour' also admitted that one of the greatest obstacles to this policy was 'colour prejudice' and that during the interwar years prejudice against half-castes was increasing. ${ }^{60}$ Such views, though they typically accompanied support for a white Australia, could obstruct this particular process as a means for achieving it. On the other hand, some proponents of racial mixing, like Griffith Taylor, remained unconvinced that a white Australia was possible (Anderson 2002:165-68).

Other key questions remain outside my terms of reference: about the diversity of views and practices relating to miscegenation; the existence of and potential for multiple explanations; and the ways in which actors themselves saw the world and understood their own motivations. Given that the removal of half-caste children is, along with the killing of Aborigines on the frontier, central to a broad and polarized debate over whether white Australians carry the guilt or not of attempted genocide, these are volatile questions (Manne 2001). It is difficult, for example, to reconcile the interpretation of assimilation in Australia advanced by Wolfe (1999:32; 2001), who conflated biological and cultural assimilation, with that offered by Paul Hasluck who as Minister for Territories helped formulate and direct the post-World War II policy of cultural assimilation. Hasluck (1988:67-68; 1995:50) argued that even those attending the 1937 Canberra conference were not proposing a 'solution' to a 'single problem' or following one particular abstract doctrine; and he insisted that, far from implementing a racial policy, most of the supporters of assimilation, including himself, were implementing their opposition to race. Arguments such as that developed by Suzanne Parry (1995) can mediate these opposed positions by proposing that well-meaning people could support or engage in actions that were facilitated by ideologies of nationalism, patriarchy, and racism without explicitly invoking them - and, I suppose, perhaps even though they might explicitly reject them. Nevertheless, such mediations do not help us to understand the different worlds in which people subjectively lived and acted.

\section{Postcolonial fortunes}

I conclude by considering the postcolonial fortunes of the word half-caste. The end of World War II entailed a retreat from racial language and the concept of race in most of the European world and a process of decolonization for the managerial colonies. In 1962, Western Samoa became the first Pacific island colony to decolonize and one of O.F. Nelson's grandsons served twice as the new nation's prime minister. In Australia, although the removal of half-caste children continued into the 1970s, the emphasis on biological assimilation had passed. Arguments for cultural assimilation, which had sometimes been separate but were also combined with the case for physical miscegenation between the wars, now prevailed. In New Zealand, the deaths of Sir Apirana Ngata and Sir Te Rangi Hiroa were mourned in 1950 and 1951 respectively, marking the departure of 
men who in their prime had embodied what some called the first Maori renaissance. And on both sides of the Tasman, the term half-caste continued to be used.

Then the politics of indigeneity shifted. From the 1970s, many persons who had been labelled half-castes, together with those who acknowledged lines of indigenous ancestry, asserted a primary indigenous identification. Simultaneously, new sites proliferated - in schools, universities, political organizations, and welfare groups - to which people identifying as indigenous, whether or not they had received from their own family a great deal of explicit lore or custom, could come for cultural enrichment. ${ }^{61}$ This shift, and in Australia the related, painful issue of the past policy of child removal, charged the word half-caste with new political significance. By calling someone 'half-caste', the speaker could be understood as denying that person's indigeneity or more generally as discounting the survival of an indigenous identity and tradition. The word has since come to be used less often than at any stage in the last two hundred years.

In Fiji and Samoa, however, local renditions of 'half-caste' remain current and can involve ambivalence. ${ }^{62}$ With independence, many people of mixed ancestry who had formerly stressed their European connection began to stress the indigenous. ${ }^{63}$ In 1987, the historian Malama Meleisea (1987:56) noted that, over the previous decade, almost half the parliamentarians in Western Samoa 'were once classified as "Europeans" or are the sons of men so classified'. More recently, in Fiji, George Speight, the coup leader of mixed European and Fijian descent, stood as an indigenous champion. But in Samoa and Fiji, too, claims to indigenous status by persons of mixed ancestry can also be disparaged by calling them half-caste. Speight was thus discredited by his critics. The leader of Fiji's earlier coups, Sitiveni Rabuka, was also reported to have said: 'I am still waiting for him [Speight] to make his announcement in Fijian'. ${ }^{64}$

The geography of time, however, is complex. Riccardo Orizio's survey of what he called The Lost White Tribes (2001) documented a tenacious pride in being 'European' among many distant descendants of white forebears in former colonies. In places where racial mixture can derive from multiple sources, a European bloodline is also sometimes vaunted above others - a point made in Teresia Teaiwa's poem (2000) describing the bitter coldness of part-European snobbery in today's Suva. There is also an echo in some more recent Maori writing of the celebration of miscegenation and the old language of race praising, for instance, 'half-caste children for their beauty, a product of hybrid vigour' (Walker 1996:28). Thus, ironically, do elements of earlier discourses about the half-caste persist. 
Foreign Bodies

\section{References}

Allen, John S. 1994. Te Rangi Hiroa's Physical Anthropology. Journal of the Polynesian Society 103:11-27.

Anderson, Atholl. 1991. Race against Time: the Early Maori-Pakeha Families and the Development of the Mixed Race Population in Southern New Zealand. Dunedin, NZ: Hocken Library.

Anderson, Warwick. 2002. The Cultivation of Whiteness: Science, Health and Racial Destiny in Australia. Carlton South, VIC: Melbourne University Press.

Andrews, C.F. 1937. India and the Pacific. London: George Allen \& Unwin.

Anon. 1929. When a Samoan is not a Samoan. New Zealand Samoa Guardian, 30 May 1929.

Austin, Tony. 1990. Cecil Cook, Scientific Thought and 'Half-castes'. Aboriginal History 14:104-22.

Australian Broadcasting Commission. 2003. Awaye! Presents Red Hot Hip Hop Writing from the Honouring Words Indigenous Writers Festival Held in Canada Late Last Year. Awaye! 28 March 2003. Sydney: ABC Radio National. Accessed 31 March 2003, online <http://www.abc.net.au/message/radio/awaye/stories/s815475.htm>.

Ballantyne, Tony. 2002. Orientalism and Race: Aryanism in the British Empire. Houndmills, Basingstoke, HAM: Palgrave.

Ballara, Angela. 1986. Proud to be White? A Survey of Pakeha Prejudice in New Zealand. Auckland: Heinemann.

Ballhatchet, Kenneth. 1980. Race, Sex and Class under the Raj: Imperial Attitudes and Policies and their Critics 1793-1905. London: Weidenfeld \& Nicolson.

Barkan, Elazar. 1992. The Retreat of Scientific Racism: Changing Concepts of Race in Britain and the United States between the World Wars. Cambridge: Cambridge University Press.

Beaglehole, Ernest. 1949. The Mixed-Blood in Polynesia. Journal of the Polynesian Society 58:51-7.

Belich, James. 1986. The New Zealand Wars and the Victorian Interpretation of Racial Conflict. Auckland: Penguin Books (NZ). 1996. Making Peoples: a History of the New Zealanders from Polynesian Settlement to the End of the Nineteenth Century. Auckland: Penguin Books (NZ).

2001. Paradise Reforged: a History of New Zealanders from the $1880 \mathrm{~s}$ to the year 2000. Honolulu: University of Hawai'i Press. 
Bleakley, J.W. 1929. The Aborigines and Half-Castes of Central Australia and North Australia. Melbourne: Parliament of the Commonwealth of Australia.

Boxer, C.R. 1963. Race Relations in the Portuguese Colonial Empire 1415-1825. Oxford: Clarendon Press.

Briscoe, Gordon. 2001. The Half-Caste Problem: Revisiting the Stolen Generation Metaphor 1900-1944. Paper to the Australian Institute of Aboriginal and Torres Strait Islander Studies, 15 November 2001. Manuscript. Canberra: Australian Institute of Aboriginal and Torres Strait Islander Studies. . 2003. Counting, Health and Identity: a History of Aboriginal Health and Demography in Western Australia and Queensland 1900-1940. Canberra: Aboriginal Studies Press.

Broca, Paul. 1864 [1860]. On the Phenomena of Hybridity in the Genus Homo, tr. and ed. C. Carter Blake. London: Longman, Green, Longman, \& Roberts for the Anthropological Society.

Brown, Malcolm. 2000. Waste of Speight. Sydney Morning Herald, 3 June 2000.

Campbell, Ian. 1999. New Zealand and the Mau in Samoa: Reassessing the Causes of a Colonial Protest Movement. New Zealand Journal of History 33:92-110.

Cilento, Raphael. 1933. The Conquest of Climate. Medical Journal of Australia. $1: 421-32$. 1959. Triumph in the Tropics: an Historical Sketch of Queensland. Brisbane: Smith and Paterson Pty Ltd.

Cocker, W.H. 1927. The Aims and Aspirations of New Zealand. News Bulletin, Institute of Pacific Relations, Honolulu, Hawaii, September 1927:34-7.

Colony of Fiji. 1874-1941a. Colonial Secretary's Office. Suva: National Archives of Fiji. . 1874-1941b. Confidential Files. Suva: National Archives of Fiji. . 1874-1941c. Provincial Council Minutes. Suva: National Archives of Fiji.

Condliffe, J.B. [1971]. Te Rangi Hiroa: the Life of Sir Peter Buck. [Christchurch]: Whitcombe \& Tombs.

Connell, John. 1987. New Caledonia or Kanaky? The Political History of a French Colony. Canberra: National Centre for Development Studies, Australian National University.

Connolly, Bob, and Robin Anderson. 1987. First Contact. New York: Viking. 
Coward, Noel. 1982. The Noel Coward Diaries. London: Weidenfeld \& Nicolson. Crosby, Alfred W. 1986. Ecological Imperialism: the Biological Expansion of Europe, 900-1900. Cambridge: Cambridge University Press. . 1994. Germs, Seeds and Animals: Studies in Ecological History. Armonk, NY: M.E. Sharpe.

Curtin, Philip D. 1990. The Environment Beyond Europe and the European Theory of Empire. Journal of World History 1:131-50.

Davidson, J.W. 1967. Samoa Mo Samoa: the Emergence of the Independent State of Western Samoa. Melbourne: Oxford University Press.

Dover, Cedric. 1937. Half-Caste. London: Martin Secker \& Warburg.

Gilson, Richard. 1970. Samoa 1830 to 1963: the Politics of a Multi-Cultural Community. Melbourne: Oxford University Press.

Hage, Ghassan. 2003. Against Paranoid Nationalism: Searching for Hope in a Shrinking Society. Annandale, NSW: Pluto Press.

Hasluck, Paul. 1938 [1836]. Our Southern Half-Caste Natives and their Conditions. Perth: Native Welfare Council. . 1988. Shades of Darkness: Aboriginal Affairs 1925-1965. Carlton, VIC: Melbourne University Press. 1995. Light that Time has Made. Canberra: National Library of Australia.

Hegarty, Ruth. 1999. Is that you Ruthie? St Lucia, QLD: University of Queensland Press.

Henriques, Fernando. 1974. Children of Caliban: Miscegenation. London: Secker \& Warburg.

Howe, K.R. 1977. Race Relations, Australia and New Zealand: a Comparative Survey 1770s-1970s. Wellington: Methuen.

Inglis, Amirah. 1975. The White Women's Protection Ordinance: Sexual Anxiety and Politics in Papua. New York: St Martins Press.

Jones, Frederic Wood. 1934. Australia's Vanishing Race. Sydney: Angus \& Robertson.

Keesing, Felix M. 1928. The Maoris of New Zealand: an Experiment in Racial Adaptation. Pacific Affairs, October 1928:1-5. . 1934. Modern Samoa: its Government and Changing Life. London: George Allen \& Unwin.

Kiple, Kenneth F. 1984. The Caribbean Slave: a Biological History. Cambridge: Cambridge University Press. 
Knapman, Claudia. 1986. White Women in Fiji 1835-1930. Sydney: Allen \& Unwin.

Lal, Brij. 1992. Broken Waves: a History of the Fiji Islands in the Twentieth Century. Honolulu: University of Hawaii Press.

Lalor, Myles. 2000. Wherever I Go: Myles Lalor's 'Oral History', ed. Jeremy Beckett. Carlton South, VIC: Melbourne University Press.

Lawry, Walter. 1850. Friendly and Fiji Islands: a Missionary Visit to Various Stations in the South Seas. London: John Mason.

Leahy, Michael J. [1933-4]. Collection of Photographs of New Guinea.

Photographs. PIC/6102 Roll 85 A3/23 LOC ALBUM 801/24. Canberra:

National Library of Australia.

Lukere, Victoria. 1997. Mothers of the Taukei: Fijian Women and 'the Decrease of the Race'. PhD thesis. Canberra: Australian National University.

McArthur, Norma. 1967. Island Populations of the Pacific. Canberra: Australian National University Press.

McGrath, Ann. 1987. Born in the Cattle: Aborigines in Cattle Country. Sydney: Allen \& Unwin. 2003. The Silken Threads of Kinship: Mixed Marriages between Asians and Aborigines during Australia's Federation Era. In Lost in the Whitewash: Aboriginal-Asian Encounters in Australia, 1901-2001, ed. Penny Edwards and Shen Yuanfang, 37-58. Canberra: Humanities Research Centre, Australian National University.

McGregor, Russell. 1997. Imagined Destinies: Aboriginal Australia and the Doomed Race Theory, 1880-1939. Carlton South, VIC: Melbourne University Press. . 1993. Representations of the 'Half-caste' in the Australian Scientific Literature of the 1930s. Journal of Australian Studies 36:51-64.

Mann, Cecil B. 1937. Objective Tests in Fiji. Suva, Fiji: Government Printer.

Manne, Robert. 2001. In Denial: the Stolen Generations and the Right. Australian Quarterly Essay 1:1-113.

Markus, Andrew. 1982. After the Outward Appearance: Scientists, Administrators, and Politicians. In All that Dirt: Aborigines 1938, ed. Bill Gammage and Andrew Markus, 83-106. Canberra: History Project Incorporated, Research School of Social Sciences, Australian National University.

Meleisea, Malama. 1987. The Making of Modern Samoa: Traditional Authority and Colonial Administration in the History of Western Samoa. Suva, Fiji: Institute of Pacific Studies, University of the South Pacific. 
Nash, Walter. 1927. A New Zealand Outlook on Pacific Affairs. News Bulletin, Institute of Pacific Relations August 1927:31-6.

Neville, A.O. [1947]. Australia's Coloured Minority: Its Place in the Community. Sydney: Currawong Publishing.

Newman, Alfred. 1881. A Study of the Causes Leading to the Extinction of the Maori. Transactions and Proceedings of the New Zealand Institute 14:459-77.

New Zealand, Department of Island Territories. 1919-40. IT series. Wellington: National Archives of New Zealand.

Ngata, Apirana. 1929a. Speech on the Mandated Territory of Western Samoa. In New Zealand, Parliamentary Debates: Legislative Council and House of Representatives, vol. 222, 903-7. Wellington: Government Printer. . 1929b. Anthropology and the Government of Native Races. In New Zealand Affairs, ed. Apirana Ngata, et al., 22-44. Christchurch: New Zealand Branch of the Institute of Pacific Relations.

Nordyke, Eleanor. 1989 [1977]. The Peopling of Hawai'i. 2nd edition. Honolulu: University of Hawai'i Press.

N.Z. Samoa Guardian. 1929-. Auckland: N.Z. Samoa Guardian Ltd.

O'Callaghan, Mary-Louise. 2000. Fiji's Future Mired in Mistrust. Australian, 22 May 2000.

Orange, Claudia. 1987. The Treaty of Waitangi. Wellington: Bridget Williams Books.

Orizio, Riccardo. 2001. Lost White Tribes: Journeys among the Forgotten, tr. Avril Bardoni. London: Vintage.

Owens, J.M.R. 1992. New Zealand before Annexation. In The Oxford History of New Zealand, ed. Geoffrey W. Rice, 28-53. Auckland: Oxford University Press.

Parry, Suzanne. 1995. Identify the Process: the Removal of 'Half-caste' Children from Aboriginal Mothers. Aboriginal History 19:141-53.

Paul, Diane B. 1995. Controlling Human Heredity: 1865 to the Present. Atlantic Highlands, NJ: Humanities Press.

Pitt-Rivers, George H. L.-F. 1927. The Clash of Culture and the Contact of Races: an Anthropological and Psychological Study of the Laws of Racial Adaptability, with Special Reference to the Depopulation of the Pacific and the Government of Subject Races. London: George Routledge \& Sons. 
Ritvo, Harriet. 1996. Barring the Cross: Miscegenation and Purity in Eighteenth and Nineteenth Century Britain. In Human, All Too Human, ed. Diana Fuss, 37-57. New York and London: Routledge.

Roberts, Stephen H. 1927. Population Problems of the Pacific. London: George Routledge \& Sons.

Salesa, Damon Jeremia. 1997. Troublesome Half-Castes: Tales of a Samoan Borderland. MA thesis. Auckland: University of Auckland.

Salesa, Toeolesulusulu D. 2000. Half-castes between the Wars: Colonial Categories in New Zealand and Samoa. New Zealand Journal of History 34:98-116.

Scarr, Deryck. 1984. Fiji: a Short History. Sydney: George Allen \& Unwin.

Shankman, Paul. 2001. Interethnic Unions and the Regulation of Sex in Colonial Samoa, 1830-1945. Journal of the Polynesian Society 110:119-47.

Shiels, Drummond. 1933. Social Hygiene and Human Welfare II: The Task of Colonial Administration. Health and Empire 7:319-31.

Simpson, J.A., and E.S.C. Weiner, ed. 1989. Oxford English Dictionary, 20 vols. 2nd edition. Oxford: Clarendon Press.

Simpson, Sam. 1974. The Part-European Community in Fiji. Suva, Fiji: South Pacific Social Sciences Association.

Sinclair, Keith. 1971. Why Are Race Relations in New Zealand Better than in South Africa, South Australia or South Dakota? New Zealand Journal of History 5:121-27.

Sorrenson, M.P.K. 1973. Review of J.B. Condliffe, Te Rangi Hiroa: the Life of Sir Peter Buck. New Zealand Journal of History 7:192-4. 1979. Maori Origins and Migrations: the Genesis of Some Pakeha Myths and Legends. Auckland: Auckland University Press.

Stepan, Nancy. 1985. Biological Degeneration: Races and Proper Places. In Degeneration: the Dark Side of Progress, ed. J. Edward Chamberlin and Sander L. Gilman, 97-120. New York: Columbia University Press.

Stewart, James, Bolton Glanville Corney, and Basil Thomson. 1896. Report of the Commission Appointed to Inquire into the Decrease of the Native Population. Suva, Fiji: Government Printer.

Stoler, Ann. 1995. 'Mixed-Bloods' and the Cultural Politics of European Identity in Colonial Southeast Asia. In The Decolonization of Imagination: Culture, Knowledge and Power, ed. Jan Nederveen and Bhikhu Parekh, 128-48. London: Zed Books Ltd.

Sukuna, Lala. 1983. Fiji, the Three Legged Stool: Selected Writings of Ratu Sir Lala Sukuna, ed. Deryck Scarr. London: Macmillan Education Limited. 
Taylor, Griffith. 1928. White and Black Races in Australia. Pacific Affairs, July 1928:1-3.

Te Rangi Hiroa [Peter Buck]. 1924. The Passing of the Maori. Transactions and Proceedings of the New Zealand Institute 55:362-74. . 1938. Vikings of the Sunrise. New York: Frederick A. Stokes.

Teaiwa, Teresia. 2000. There Is No Poetry. In Teresia Teiawa and Sia Figiel, Terenesia. CD recording, track 14. Honolulu: Hawai'i Dub Machine and 'Elapaia Press.

Thomson, Basil. 1908. The Fijians: a Study in the Decay of Custom. London: William Heinemann.

Tindale, Norman B. 1941. Survey of the Half-Caste Problem in South Australia. Adelaide: Royal Geographical Society, S.A. Branch.

Walker, David. 1999. Anxious Nation: Australia and the Rise of Asia 1850-1939. St Lucia, QLD: University of Queensland Press.

Walker, Ranginui. 1990. Ka Whawhai Tonu Mätou: Struggle Without End. Auckland: Penguin Books (NZ). . 1996. Ngā Pepa a Ranginui: the Walker Papers. Auckland: Penguin Books (NZ).

Wareham, Evelyn. 2002. Race and Realpolitik: the Politics of Colonisation in German Samoa. Frankfurt am Main: Peter Lang.

Webb, T.T. n.d. [early 1940s]. A Future for the Half-Caste. Sydney: Methodist Overseas Missions.

Wilson, Ronald. 1997. Bringing Them Home: National Inquiry into the Separation of Aboriginal and Torres Strait Islander Children from Their Families. Sydney: Human Rights and Equal Opportunity Commission.

Wolfe, Patrick. 1999. Settler Colonialism and the Transformation of Anthropology: the Politics and Poetics of an Ethnographic Event. London and New York: Cassell. 2001. Land, Labor, and Difference: Elementary Forms of Race. American Historical Review 106:866-905.

Yarwood, A.T. 1991. Sir Raphael Cilento and the White Man in the Tropics. In Health and Healing in Tropical Australia, ed. Roy MacLeod and Donald Denoon, 47-63. Townsville: James Cook University.

Young, Robert J.C. 1995. Colonial Desire: Hybridity in Theory, Culture and Race. London and New York: Routledge. 


\section{Notes}

${ }^{1}$ Despite the ugly implications of terms like 'half-caste' and 'mixed race', I use them freely in this discussion because of their historical aptness. Inverted commas are omitted except when quoting but are always implied.

2 See, e.g., Keesing 1934; Pitt-Rivers 1927; Roberts 1927; Tindale 1941.

3 The record is lost but the song was composed in 1930 (Coward 1982:396).

${ }^{4}$ I am grateful for comments on this subject from Tim Rowse, referring particularly to doctoral research currently being done by Mark Hannah at The Australian National University on the regulation of Aboriginal marriage, and from Donald Denoon. See also Markus 1982.

${ }^{5}$ Most of the etymological information derives from the second edition of the Oxford English Dictionary (Simpson and Weiner 1989, II:953-4; III:55; VI:1035).

${ }^{6}$ See Boxer 1963; Henriques 1974; Stoler 1995.

7 See, e.g., G.S. Richardson, Private Notes on Administration of Western Samoa, n.d., in New Zealand Department of Island Territories 1919-40: IT 1 Exl/42 pt 1. For a general discussion of similar themes, see McGrath 1987:70-2.

8 Patrick Wolfe (1991:179-81), however, construed the half-caste as a grave threat to white identity in Australia while Cecil Cook, who features in the main text of this discussion, was one contemporary who feared the male half-caste as a dangerous element in the population of the Northern Territory (Austin 1990:113, 115, 116, 117, 119).

9 Connolly and Anderson 1987:242-3.

${ }^{10}$ Leahy [1933-4].

11 Connolly and Anderson 1987:278.

12 Children of mixed but non-European ancestry raise questions that will scarcely be touched here (but see Lukere 1997:211-34; see also McGrath 2003; Shankman 2001; Wareham 2002). To say that the ancestry of the European half-caste is archetypically white on the father's side and coloured on the mother's can, of course, travesty the ancestry of individuals whose parents might both have had European forebears. Half-castes of later generations classified as 'Europeans', however, as a general rule inherited this status, along with a European surname, through a legally recognized patriline.

13 Resolution 10 Concerning Jese Tagivaitana, Report of the Provincial Council of Tailevu, Nausori, 20 January 1892, in Colony of Fiji 1874-1941c: Resolutions 1892-94, Book No. 1, Tailevu.

14 Superintendent of Police, Recommendation of the Removal of Mrs Murdock from the Colony, 17 January 1878, in Colony of Fiji 1874-1941a: Colonial Secretary's Office, CSO 78/93.

15 Tindale 1941:82, figure 4.

${ }^{16}$ Lawry's vision of miscegenation can also be seen in terms of the Christian Evangelical tradition which contained within it creeds opposed to the racial compartmentalization of humanity. See Chapters Six (Gardner) and Seven (Weir), this volume.

17 Cilento (1959:437) remarked that the Australasian Medical Congress in 1920 had, in opposition to traditionalists, affirmed the feasibility of the white colonization of the tropics. Aside from 'traditionalists' within medical circles, some prominent geographers remained doubtful and, as David Walker (1999:153) observed, 'the stigma of tropicality' persisted until the late 1930s. For a fuller discussion of perduring misgivings, see Anderson 2002:164-74.

18 Cook, quoted in McGregor 1997:169; Yarwood 1991:54-5.

19 During the interwar era, Cuba and Puerto Rico were virtually the only colonies within the tropics where people of predominantly European descent comprised the majority (Kiple 1984:7). In New Caledonia and Hawaii, the Pacific Island groups with the largest European populations at that time, whites were — and remain still — a minority (Connell 1987:97; Nordyke 1989:178-9). For these reasons, Cilento (1933:432) stressed Australia's uniqueness: 'we have a greater population, purely white, living in the tropics than any other country in the world can boast'.

${ }^{20}$ For a general discussion of pejorative characterizations of people of mixed race, see Stepan 1985:104-12. See Chapter One (Douglas), this volume, on the key status of racial mixing in scientific debates about the unity or plurality of human species from the mid-eighteenth century and on the racialism of arguments both in favour of and against human hybridity.

${ }^{21}$ Defoe quoted in Dover 1937:99; Thomson 1908:ix; see also Barkan 1992:23.

22 Ritvo 1996:41; Stepan 1985:106; Young 1995:8. 


\section{Foreign Bodies}

23 Paul 1995:110-11; Ritvo 1996:45; Stepan 1985:106, 108; Young 1995:11-12. The question of the infertility or otherwise of hybrids was pivotal in naturalists' debates on the concept of species at least from the mid-eighteenth century. The French anatomist and anthropologist Paul Broca (1824-1880) based his influential short monograph on human hybridity - the first systematic study of the subject, quickly translated into English (1864) - on a thorough study of hybridity in animals. See Chapter One (Douglas), this volume.

24 See Chapters Two (Douglas), Four (Turnbull), and Five (Anderson), this volume.

25 Anderson 2002; Hage 2003:47-68; Ballara 1986; Belich 2001:223-31.

26 Hasluck 1938:24; Hegarty 1999:7-8; Lalor 2000:38-41; Tindale 1941:76; Wilson 1997:135.

27 For a discussion of problems relating to data for Aboriginal populations in Western Australia and Queensland in the period from 1900 to 1940, see Briscoe 2003:1-78.

28 Quoted in Neville [1947]:27, original emphasis.

29 Tindale 1941:116-24, 125-35; Wilson 1997:39-150.

30 Hasluck 1938:16-17; Wilson 1997:212-20.

31 Australian Broadcasting Commission 2003.

32 Connolly and Anderson 1987:276-7.

33 Joseph Waterhouse, Drawing Attention to the Fact that Two White Children are Living under the Care and Control of Native Polynesians, 18 April 1878, in Colony of Fiji 1874-1941a: CSO 78/93.

Waterhouse had inherited a set of Christian and humanitarian values that often stressed the fundamental unity of humankind and discounted the spiritual significance of racial divisions. See Chapters Six (Gardner) and Seven (Weir), this volume. Nevertheless, as this instance illustrates, racial markers such as skin colour could continue to be used as signifiers of cultural difference and social status.

34 Jones 1934:39-40; Tindale 1941:79-81.

35 Anderson 2002:181-215; McGregor 1997:156-61; Tindale 1941:87.

36 Anderson 2002:199-206; Taylor 1928:3.

37 Sorrenson 1979:19-33; Ballantyne 2002:56-82. This is what James Belich (1996:20) called the 'white' lens of the 'race-bow' through which white New Zealanders saw Maori as 'quite European-like', 'the best of savages'.

38 Cocker 1927; Nash 1927; Te Rangi Hiroa 1924; see also Sinclair 1971:124.

39 Allen 1994; Te Rangi Hiroa 1938:14-15.

40 Maori transliterated the term half-caste and Te Rangi Hiroa on occasion publicly described himself as 'half-caste' (Allen 1994:20). Mixed ancestry was also an important feature of Carroll's personal and public identity. Pomare and Ngata had European forebears on the maternal side but their white ancestry was less stressed. For a detailed biography of Te Rangi Hiroa, see Condliffe 1971.

41 A few years after Te Rangi Hiroa's repudiation of Newman, the anthropologist Felix Keesing (1902-1961) in turn percipiently challenged the prognosis of a fully acculturated and assimilated future for Maori (1928:5). He foresaw educated Maori, including those with European ancestors, rejecting 'passive absorption' and promoting among Maori 'the fire of race-consciousness and vitality'. Keesing also observed, at odds with the tendency to celebrate miscegenation, that interracial marriages in New Zealand were now fewer due to racial prejudice.

42 The wave of revisionist historiography since the 1970s includes the writings of Maori like Ranginui Walker (1990), who stressed the brutal impact of European colonization on Maori and an uninterrupted history of their resistance; and a series of critical studies by Belich who, beginning with The New Zealand Wars (1986), endeavoured to place New Zealand's colonial history within a broader comparative framework $(1996,2001)$.

43 This chapter was first written without the benefit of Toeolesulusulu Salesa's sensitive meditation on half-castes in New Zealand and Western Samoa between the wars. Whereas Salesa (2000:99) at the outset stressed the ways in which the fortunes of half-castes in each context shaped each other, my starting-point has been the disjunctions between these histories.

${ }^{44}$ For a discussion of the legal complexities, however, see Shankman (2001) and Wareham (2002).

45 See, e.g., Juxon Burton, Minute on Tourists and Fijians, 29 July 1936, in Colony of Fiji 1874-1941b: CF $50 / 12$.

${ }^{46}$ In the context of this volume, Fiji is an interesting case because its native policy was founded on a conscious rejection of the nineteenth-century conviction that races like the Fijians were congenitally doomed (Lukere 1997:29-50). 
47 For a history well attuned to the racial dimensions of Fiji's twentieth century, see Lal 1992.

48 Andrews 1937:114; Mann 1937:7-8; Scarr 1984:143, 156.

49 Davidson 1967:76-113; Meleisea 1987:48-51, 128-30.

50 A further 959 'Europeans' were Chinese. Under the Samoa Act of 1921, 'A European is any person other than a Samoan' (quoted in McArthur 1967:118). The actual ethnic composition of the 'European' category was therefore difficult to analyze precisely (Keesing 1934:32).

51 Keesing 1934:37-40; Wareham 2002:177-178.

52 Gilson 1970; Salesa 1997; Shankman 2001.

53 See, e.g., comments by the Military Administrator of Western Samoa: Robert Logan, Report for Governor General on Administration of Samoa, 8 July 1919, in New Zealand Department of Island Territories 1919-40: IT1/10: 32-3.

54 Stephen S. Allen, Telegram to Department of External Affairs, 3 April 1930, in New Zealand Department of Island Territories 1919-40: IT 1 Exl/23/8 pt 18.

55 Ian Campbell's reassessment of the Mau (1999) came close to the contemporary official interpretation of Nelson's involvement and also recognized New Zealand's good intentions under the terms of the mandate.

56 See Richardson to Sir Frances Bell, 27 December 1926; Richardson to Minister of External Affairs, 13 December 1926; Richardson to Nosworthy, 26 July 1927; G.S. Richardson, Memo to Minister for External Affairs, 24 June 1927; and Bell to Richardson, 29 January 1925, in New Zealand Department of Island Territories 1919-40: IT 1 1/33/1 pt 1; IT 1 Exl/23/8 pt 2; IT 1 Ex 1/33/1 pt 1. While anti-German feeling had been inflamed by the war and New Zealand officials were, for other reasons, mistrustful of German elements within Western Samoa and acutely sensitive to unfavourable comparisons with the earlier German regime, these anti-German sentiments cannot totally explain the administration's hostility towards half-castes in Samoa, as the parallels with Fiji, where the British did not have a comparable German element or legacy, suggest.

57 N.Z. Samoa Guardian, 12 December 1929:1.

58 For a discussion of the policies towards miscegenation in Western Samoa during the German administration, see Shankman (2001) and Wareham (2002).

59 Ngata 1929a:906; see also 1929b:43-4.

60 Neville 1947:72; Tindale 1941:122.

${ }^{61}$ See, e.g., Walker 1996:110, 164-7, 168-9.

62 In Fiji, the English word half-caste is often used though the Fijian term is kai loma, 'person in the middle'. In Samoan, the words are totolua, 'two blood', or 'afakasi, the latter transliterating the English word.

63 Meleisea 1987:179-80; Simpson 1974:19.

64 Brown 2000; Sitiveni Rabuka quoted in O'Callaghan 2000. 